Journal of Sustainable Development of Transport and Logistics

journal home page: https://jsdtl.sciview.net

Bayane, B. M., \& Yanjun, Q. (2020). Past, present and future development of West African railways. Journal of Sustainable Development of Transport and Logistics, 5(1), 103-114. doi:10.14254/jsdtl.2020.5-1.10.

\title{
Past, present and future development of West African railways
}

\author{
Bouraima Mouhamed Bayane *(D), Qiu Yanjun **(D) \\ * School of Civil Engineering, Southwest Jiaotong University, \\ Chengdu, Sichuan 610031, China \\ ** Key Laboratory of Highway Engineering, Sichuan Province, Southwest Jiaotong University, \\ Chengdu, Sichuan 610031, China
}

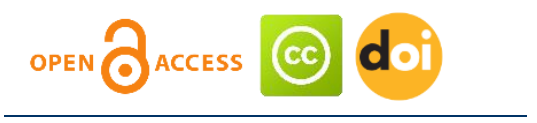

Article history:

Received: February 26, 2020

1st Revision: March 20, 2020

Accepted: April 12, 2020

DOI:

10.14254/jsdtl.2020.5-1.10

\begin{abstract}
In view of the crucial role, railways have played historically inland transportation, the West African region still endure to provide an efficient transport system. While road transport has been almost the exclusive predominant transportation mode in the region, the railway is now showing a global comeback. In the absence of a new phase of modernization at the international standard, it is unavoidable that the high demand for mobility of its increasing population and the full exploitation of its natural resource endowment will be constrained. This study presents the past, present, and future developments of the railway sector. The first section includes the brief historical development of the railways, the determinants choices of their location, and the influential parameters for their construction. The second section deals with the present state of the railway infrastructure, operational performance, and railway sector institutions. The last section provides some recent investment in the key construction projects at a national level.
\end{abstract}

Keywords: West African railways, transportation, road transport.

\section{Introduction}

A global renaissance has recently been felt in railway transportation through the total length of its network and annual traffic units. This revival of the railways is pertaining to their considerable socio-economic, environmental costs and benefits generated by the transport sector (Bayane \& Yanjun, 2017). As a consequence, an absolute corporation for railways is a precondition for transportation operation services since it remains the principal mover of people and heavy freight over the middle to long distances. There is an opportune chance to develop railway when combining the apparent economic growth in West Africa in addition to the arisen middle class and unutilized resources (Olievschi, 2013). Thus, the extension of the railway network has been decided by the African Union to meet the aspiration of its agenda by 2063 (A. Union, 2015).

Corresponding author: Qiu Yanjun

E-mail: publicqiu@vip.163.com

This open access article is distributed under a Creative Commons Attribution (CC-BY) 4.0 license. 
The objective of this paper is to present the past, present, and future development of the railway transportation system in West Africa. The past or background of the railway transportation system covers the historical development of railway construction, the determinants of the choice of railways location and the influential parameters of railway construction. The present state of the railway covers its infrastructure (track density and operated gauges), operational performance (traffic density and labor productivity), and railway sector institutions. The future development comprises of investment and key construction projects on the railway sector.

\section{Methodology}

The methodology in this paper consists of the utilization of major sources from a practical survey, analysis of evidence from the experimental study as well as analysis of data from different published sources. The list of selected countries consists of Benin Republic, Burkina Faso, Ghana, Guinea, Ivory Coast, Liberia, Mali, Nigeria, Senegal, Sierra Leone, and Togo.

\section{Background of railway transportation}

\subsection{Historical development of railway construction}

In West Africa, the construction of the first rail line started from Dakar to St Louis Dakar at the mouth of the Senegal river in 1885 (Ogunremi \& Faluyi, 1996). The Dakar-St Louis line got to Bamako (Mali), 1159 km inland, in 1923 (Ogunremi \& Faluyi, 1996). In Ivory Coast, the railway construction began in 1903 and the line got to Bouake, $315 \mathrm{~km}$ inland, in 1912 (Ogunremi \& Faluyi, 1996). In Burkina Faso, Ferkessedougou (558 km) and Bobo Dioulasso $(796 \mathrm{~km})$ were reached in 1926 and 1934 respectively but the line never got to Ouagadougou at this time (Ogunremi \& Faluyi, 1996).

Railway in the Benin Republic (previous Dahomey) was built between 1905 and 1913 (Pobè to Porto-Novo line) and was extended to Cotonou, $106 \mathrm{~km}$ in all, between 1928 and 1930 (Bouraima \& Qiu, 2018). As for Togo, three metrics gauge lines were constructed by the Germans: the central line from Lomé to Atakpame, 1934; the Lomé-Aného and Lomé-Kpalimé lines (Ogunremi \& Faluyi, 1996). In Nigeria, construction started in Lagos in 1898 and the line was extended to Ibadan in 1901, Jebba on the Niger in 1909 and Kano, 1145 km inland, in 1911 (Ogunremi \& Faluyi, 1996).

In Ghana (Gold Coast), the construction of railway proceeded from Accra in stages: Tarkwa was reached in 1901 and Obwasi in 1902 (Ogunremi \& Faluyi, 1996). The Accra-Kumasi and Accra-Sekondi lines were accomplished in 1923 and 1927 respectively (Ogunremi \& Faluyi, 1996). A meter-gauge railway line was built from Conakry to Kankan, in inland Guinea close to the Mali and Ivory Coast borders, in 1914 (Metcalfe, 1916). In Sierra Leone, the first railway in British West Africa was built in 1896 linking the fine harbor at Freetown to Pendembu, a distance of $366 \mathrm{~km}$ (Metcalfe, 1916). In Liberia, with a total length of $490 \mathrm{~km}$, three long-distance railway lines comprise of a Mano River line running from the river border with Sierra Leone inland to Monrovia, another running from Bong County to Monrovia and a third from Yekepa in Nimba Country to the port of Buchanan were respectively built in the early 1960s (Graham, Garrido, \& Karjanlahti, 2012).

\subsection{Determinants of the choice of railways location}

The construction of railways was governed by different factors. As the wealth of West Africa is immense, and inhospitable coasts and few good harbors have characterized its transportation system, the first practical consideration which motivated the construction of the railway is the question of ports (Captain H.O. \& Mance D.S.O., 1913). In West French Africa, the transcontinental railway networks were thus projected by colonial governors aiming at serving the ports as feeders and link to the countries of the hinterland (Debrie, 2001). The penetration and conquest of French and British colonial governments in West Africa have resulted in several footholds for them along the Guinea Coast through seaports and feeders' railways.

Compare to British power, most of the territories were under French control which explains a number of rail lines that serve ports on the Western and Southern coasts (Dakar-Niger, Abidjan-Niger, and Benin-Niger), and railways connection between Senegal and Mali, and Ivory Coast with Burkina 
Faso. On the British side, the constructed rail lines were connecting with the coastal terminals at the major port of Tema in Ghana, Lagos and Port-Harcourt ports in Nigeria, the port of Freetown in Sierra Leone, and the port of Monrovia in Liberia.

Prior to the attainment of their independence in West Africa, numerous countries were endowed with one or other forms of mineral resources. In addition to natural resources, most of them are known to be largely dependent on rich agricultural potential. This immense wealth of West Africa in terms of agricultural products and minerals has thus become a spur of rapid construction of transport lines for export during the colonial period. As a matter of fact, natural resource exploitation was the main reason for rail penetration (Taaffe, Morrill, \& Gould, 1963).

In the case that railways systems are under different administrative control, there is an occurrence of harsh competition between them. For instance, neighbors and rivals, the French and Germans colonial powers built parallel rail penetrating from narrow openings on the Gulf of Guinea: Cotonou-Parakou line meets Lomé-Sokodé line (Pourtier, 2007).

When looking at the colonial railway networks, the early construction was following the route with cheaper and modest investments (Rémi Jedwab, Kerby, \& Moradi, 2017), which could explain that the physical configuration with the higher ultimate expense for construction was avoided (Jaekel, 1997). This explains the avoidance of deep cuttings, long-span bridges, tunnels and viaducts, and high embankments. The Baro-Kano railway line in Nigeria is an illustration, where British colonial power has considered lower-cost construction and the best possible grade with the easy ability of improvement as traffic increased (Sunderland, 2017).

The delimitation of the territory was also considered as another factor when the railway system should be constructed, as the West Africa region is mostly fragmented between different colonial superpowers. Prior to the construction of the railway which is considered as colonialists' first ally, colonial engineers used to imposed their order on the unknown African landscape, control times and distances within the unspecified territory (Scotto, 2018), which will avoid the difficulties or confrontation from different colonial powers as it was the case on the French Guinea railway construction between British and French (Thomas, 1957).

\subsection{Influential parameters of railway construction}

During the colonial period, the construction of the railway was undertaken by the colonial governments, since it was seen as an instrument of effective occupation (Mabogunje, 2015). The construction of the railway in Senegal was planned to secure for France the basin of the upper Niger, to extend colonial control and expand the economic exploitation of French West Africa (AOF), and to facilitate the penetration of West Africa in the south of Sahara (Robinson, 2007). The Ivory Coast railway was undertaken to link Grand Bassam to Kong (important caravan center), and give a maritime façade to the territory already occupied in Sudan (Brou, 2015). The railway was extending to Burkina Faso in order to have access to the territory (Nana, 1984). It is the same scenario in the Benin Republic (previous Dahomey), where access to hinterland countries was among the motivation of railway construction (Bouraima \& Qiu, 2018). In Liberia, lines were originally built mainly to transport iron ore from the mine heads in the Western cluster and in Bong to the port of Monrovia as well as from the mines in Nimba (near the Guinea border) to the port of Buchanan (Graham et al., 2012). However, this effective occupation by colonial powers that motivated the construction of the railway through the region was temporary.

Another factor based on the economic grounds was taken into account since it was strategic and will mostly impact the order in which the component projects were accomplished. The case of Nigeria is an example where the original conception of the railway was to consolidate power in the newly acquired territory, and opening up of the country to trade with England (Ademiluyi, 2006). As for the development of commerce and commercial agriculture, northern Nigeria was linked to the southern part, which improves the country's prosperity through the expansion of its market product and enhances productivity (Adesanya, 2010). The administration reason through the intercommunication between different areas of the same colonial administration was also among the object of railway construction. In Nigeria, the railway was constructed to link the central seat of the colonial government in Lagos with other parts of the country (Agbaeze \& Onwuka, 2014). 


\section{State of rail infrastructure in West African countries}

\subsection{Overview}

Although the railways have the capacity to be more advantageous where substantial savings enable, West African countries have wrestled to obtain the profits. The common appearance of railways in West African countries mirrored deteriorated infrastructure, obsolete technologies, and low-quality operations regarding safety and performance (Bayane, Yanjun, \& Bekhzad, 2020). This can be explained by the fact that the national transport sector plan has favor road transport mode over its rail counterpart. This undoubtedly explained why more funds are given to road transport instead of the railway because of its sustainability and immediate operation (Bouraima \& Dominique, 2018). After many years of inadequate maintenance and scarcely accessible investments, most of the countries within the region have main railways sections that are inoperable and necessitate renovation. Overall, the railway infrastructure in West Africa is in poor condition. For instance, the Cotonou-Ouidah, Pahou-Sègbohouè, Cotonou-Pobè, viz Porto-Novo and Abomey-Zagnanado via Bohicon lines are not operational in the Benin Republic; the 104-kilometer section between Ouagadougou and Kaya are out of service since 2003 in Burkina Faso (Bayane et al., 2020). As for Ghana, except the Accra to Tema, Accra to Kotoku, Awaso to Dunkwa and south to Takoradi lines, $60 \%$ of the total railway network are inactive (Bullock, 2009).

The poor quality and the deficient size of the network has exceptionally affected the regional network of landlocked countries of Burkina Faso, Mali, and Niger and inflicted huge freight costs for three reasons. First of all, the limited length and quality of the railway lines decreased the freight volumes that line should bear, influencing severely efficiency and labor productivity. Next, the restricted length of rail routes shows that freight has to be shifted to road transport in order to get the final destinations, which raises the costs in comparison to only road transport mode. Lastly, a variety of track gauges experienced within the region contribute to the hindrance of a balance traffic flow on the railway networks.

\subsection{Infrastructure}

In West Africa, freight is principally being transported on the railway infrastructure (Fig. 1) because of the innumerable natural and mineral resources that characterized many countries of the region. As $90 \%$ of regional importation and exportation traffic are conveyed through the sea, most of the railway lines are connected to mining zones and ports (AfDB, 2015). Nevertheless, there is a restriction in the transportation of people and goods in the region because of the small connectivity between national railway networks. Only a smaller number of lines traverse borders, such as Sitarail between Burkina Faso and Ivory Coast, and Transrail between Mali and Senegal. A variety of track gauges ranging from narrow $(600 \mathrm{~mm})$ to standard $(1435 \mathrm{~mm})$ operated in several countries. Metric gauge lines of $1000 \mathrm{~mm}$ are mostly used in all French-speaking countries while the Cape gauge $(1067 \mathrm{~mm})$ predominates in English speaking countries (Gwilliam, 2011), followed by the standard gauge $(1435 \mathrm{~mm})$, which are more recently constructed. Figure 2 showed the operated track gauges found in the Western region of the continent. Attempts in constructing modern tracks gauge appear to overlook interest in existing infrastructure.

Literature available so far indicates that not only track quality but also its density is beneath international standards in West Africa. Most of the railway's assets are more than a century old, and as a consequence, the quality of their track materials is significantly obsolescent (Bayane et al., 2020). All the early railway tracks in West Africa are ballasted; however, they are not properly or habitually maintained. The combined effect of aging infrastructure, tamping and deficient maintenance has seriously impacted the operational performance of railways in the region. Firstly, the maximum axle load that the railway structure can bear in West Africa is roughly 17 tonnes (Bayane et al., 2020). Comparatively, the standard axle load in European countries is greater than 25 tonnes (E. Union, 2004). The poor track quality influences the maximum speed achieved in these networks. According to (Bayane et al., 2020), the freight trains in West Africa reached only an average speed of $30 \mathrm{~km} / \mathrm{h}$. 
Figure 1: Track density in West African countries

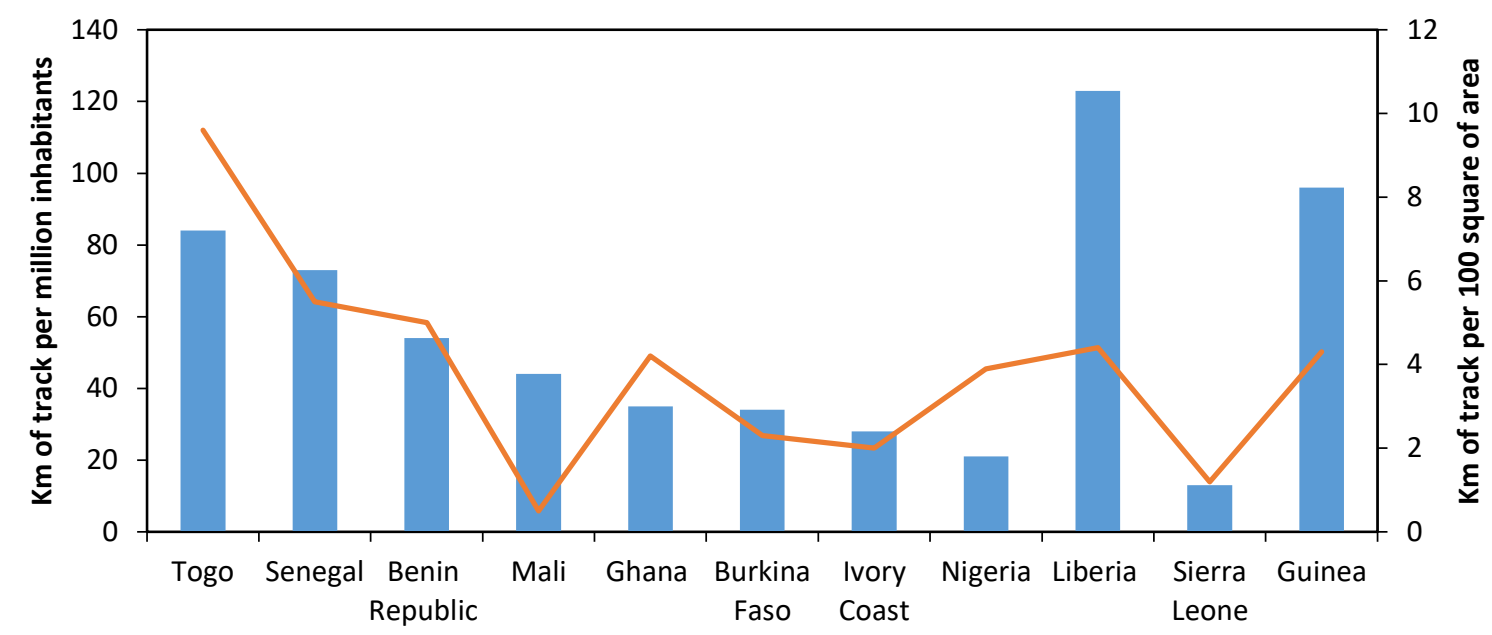

Figure 2: Track gauges operated in West African countries

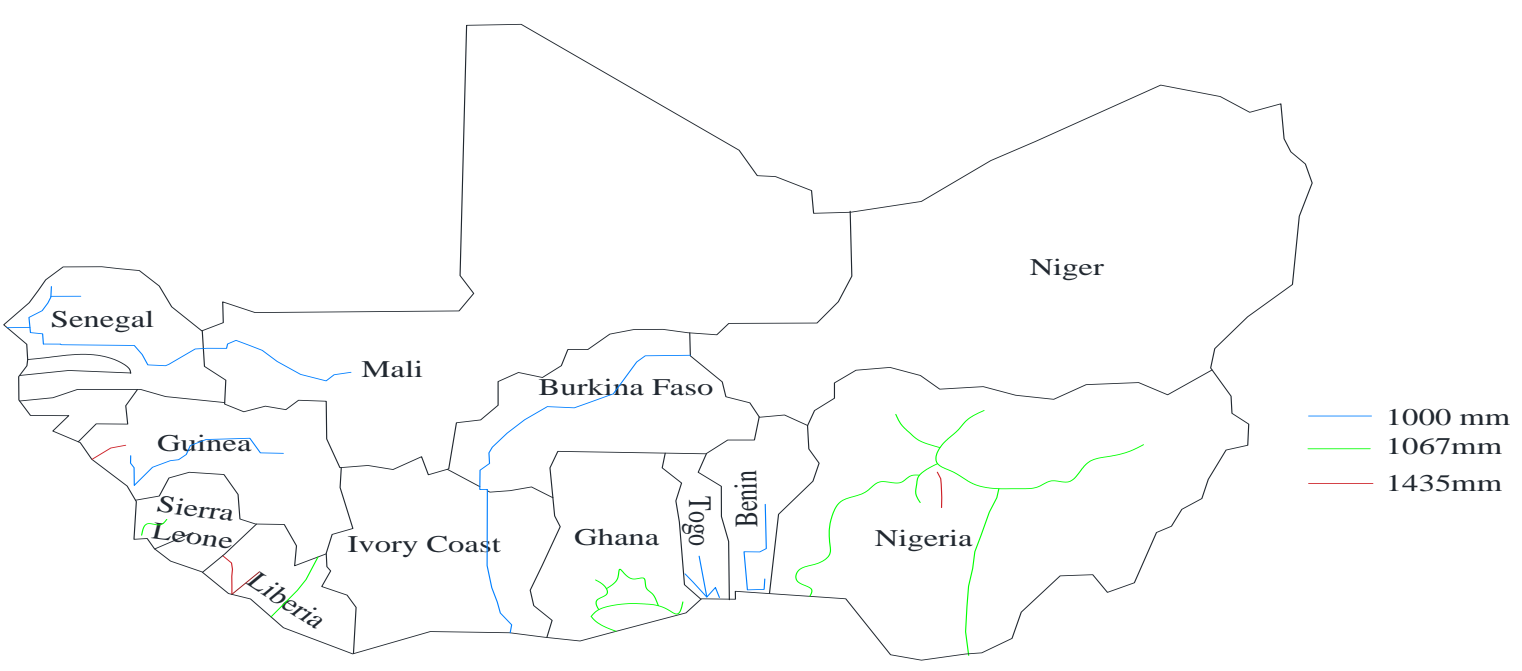

Practically all the networks are single track except the $70 \mathrm{~km}$ double track of Dakar-Thies line in Senegal, and the first $30.6 \mathrm{~km}$ of the Western line (Takoradi-Manso) in Ghana (Bayane et al., 2020). Diesel locomotives are used in the existing railway tracks because of a lack of electrification in their networks. The platforms and sidings are obsolete and have existed since the construction of the first original lines. Signaling on railway networks is mostly done through manual systems whether with manual train's orders or mechanical signals (Bayane et al., 2020). The adequacy of manual systems is obvious in the very low traffic actually made on most lines, however, safety problems often happen because of human error. Signaling systems are determined as an obstacle that needs to be controlled in order to increase the traffic without danger.

\subsection{Operational performance}

The railway traffic in West African countries is mostly freight services that represent almost a huge percentage of regional traffic. This is due to the difficulty to get back the costs of passenger operations because of a lack of subsidies and poor track conditions. The combined effect of low axle load and limited speed reached on most of the damaged existing lines has considerably affected the regional traffic volume. Traffic volumes are a fundamental scale of the viability and cost-effectiveness of operational railways because they underline the utilization of the infrastructure. The ability of rail transport to compete with other modes is based on the huge volume of traffic carried, which will produce large funds for infrastructure maintenance (Bayane et al., 2020). Bayane et al. (2020) in their study have shown that with exception of Guinea where the private mining companies significantly 
used the railway's lines, the rest of the West African countries have a traffic density below 1 million traffic units (passenger-km plus tonne-km) per route-km (Fig. 3).

Figure 3. Rail traffic density in West African countries

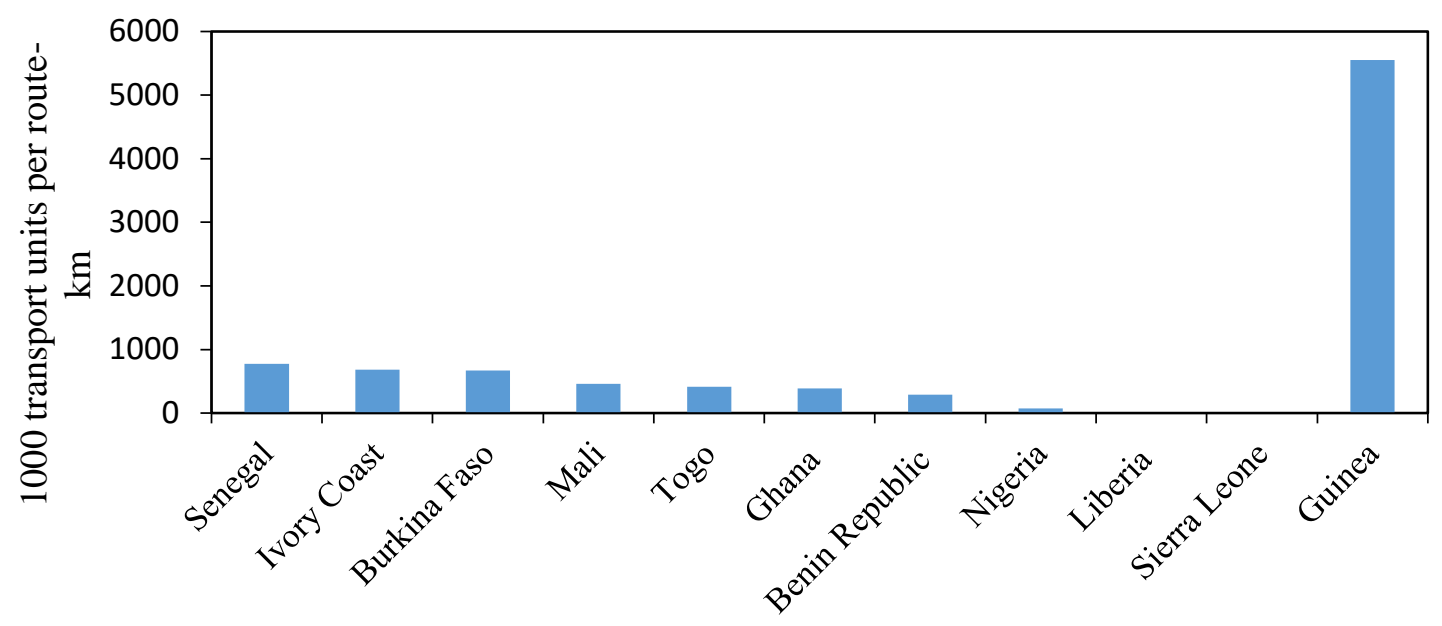

Also, low labor productivity has been noticed due to low traffic volumes (Fig. 4). Safety along the railway network has been another issue. Worse state of safety records through derailments and thievery of infrastructure have been highlighted based on the available data (Bayane et al., 2020).

\subsection{Railway sector institutions}

Powerful institutional and regulatory frameworks that secure investment are primordial for the development of the railway. Adequate regulations and policies are implemented and formulated based on the degree of involvement of government actors in the railway industry. Some countries have established the regulation and legal system in order to monitor market performance, safety issues, and corruption. While some countries like Ghana and Nigeria have enacted Act 2008 and Act 1955 for the establishment of their railway corporations respectively, the railway in the Benin Republic is still public enterprise without any regulatory body. The institutions of the railway sector of each country within the region are presented in Table 1.

Figure 4. Labour productivity in West African countries

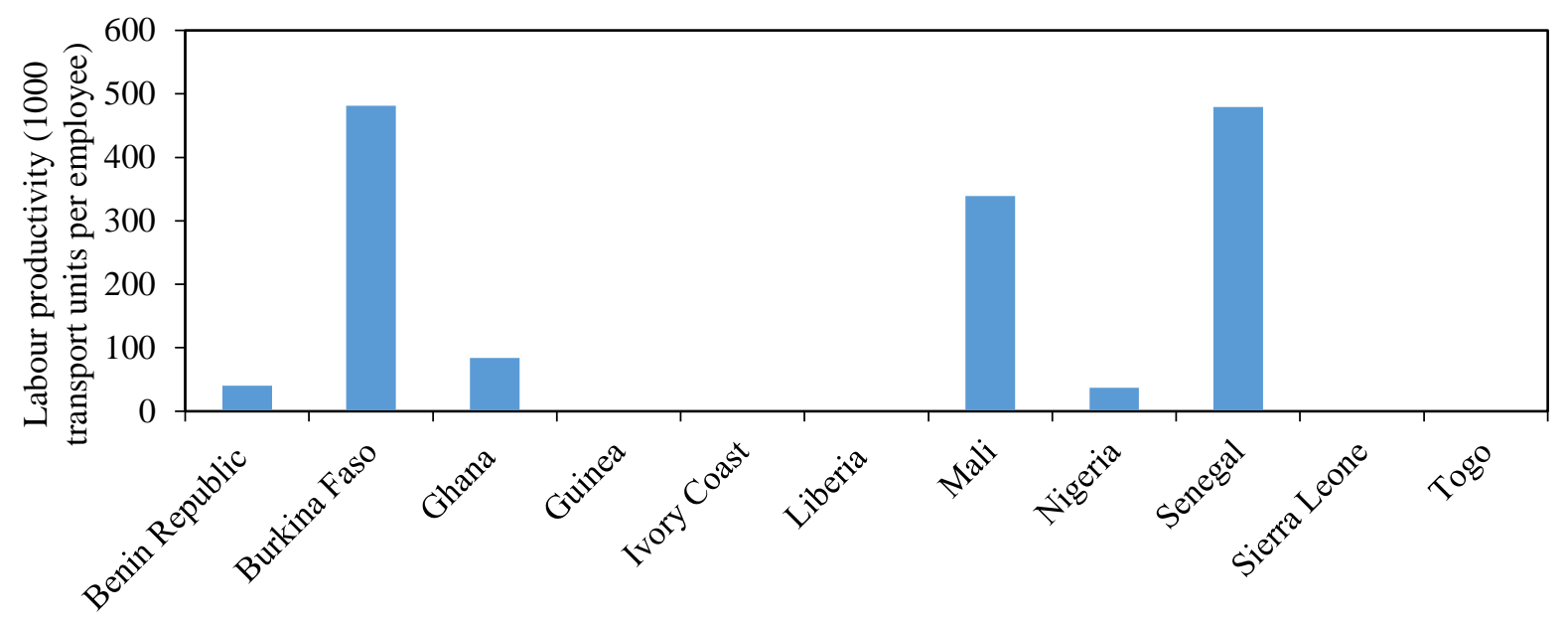




\section{Future railway development}

As stated above, much of West African's existent railway infrastructure is mostly inherited from the British and French colonial period. After independence, nonetheless, the increasing costs of corruption and government bureaucracy, together with the decrease applicability of agricultural exports, meant that network progressively deteriorated. As stated by Remi Jedwab and Storeygard (2019), transport infrastructure in Africa is characterized by a restricted network, poor condition, and operated below design capacity, which worsens transport challenges for inland countries with export prospects. Recently, after decades of neglect, many Africans governments have sought the participation of a number of actors in this effort. Organization for Economic Co-operation and Development (OECD) investors, conventional Official Development Assistance (ODA), and non-OECD countries have mostly funded African infrastructure (Foster, Butterfield, \& Chen, 2009). In the railway sector, the development comprises the rehabilitation of existing railway lines and the construction of a new railroad.

\section{Table 1: institutions of the railway transportation system in West African countries \\ Countries Institutional framework}

\section{Benin}

Republic

Organisation Commune Bénin-Niger des Chemins de Fer et des transports

(OCBN). Involved in the administration and management of the Benin-Niger railways, the compensation operation of the rail-road transport modes and ancillary transport activities. Established in July 1959 by the governments of Niger and Benin Republic through a memorandum of understanding under a protocol of agreement. General Directorate of Land Transport under the Ministry of Public Works and Transport. Responsible for the regulation of road and rail transport, issuance and control of travel documents, transport authorizations and the coordination of road freight. Also responsible for project delivery and infrastructure construction.

Ministry of Economy and Finance. Decided on the allocation of budget funds among different projects and responsible for dealing with multilateral and bilateral financial agencies.

Burkina Faso Railway Heritage Management Company (SOPAFER-B) under the control of the Ministry for Infrastructure, Opening and Transport. Managed railway assets and infrastructure. Established by the government in 1990.

Sitarail (International Company of African transport by rail). Operated commercial freight and passenger transport services between Ivory Coast and Burkina Faso.

Ghana Ghana Railways Company (GRC). National Corporation under the control and supervision of the Ministry of Transport.

Ghana Railway Development Authority (GRDA). Established by the railway Act 2008 on November 14, 2008. Responsible for the growth and advancement of railway services.

Ghana Railway Company Ltd (GRCL). The private company is responsible for purchasing the operability and maintenance of the railway during the transition to the private sector.

Guinea National Society of Railways of Guinea (SNCFG). A public company under the supervision of the ministry responsible for transport and is responsible for: i) the organization, management, and operation of the rail freight transport network and passengers throughout the national territory, ii) the execution and control of new works or major repairs concerning railway installations and their annexes, when these works cannot be dissociated from operations, iii) participation in the promotion of the rail transport network among donors and potential investors, v) participating in the development and implementation of railway construction projects by acting as an interface between the State and companies of construction (validation and adoption).

Ivory Coast Ivorian Railway Heritage Company (SIPF). Received an attribute from the state to monitor and control different tasks.

The Directorate General of Land Transport and Traffic (DGTTC) under the Ministry of Transport. Responsible for leading the national policy on land transport, road and rail traffic and coordinating the activities of the directorates and service under its authority.

\section{Are regulatory \\ bodies in place and operational} No

No Yes 


\begin{tabular}{|c|c|c|}
\hline Liberia & $\begin{array}{l}\text { National Iron Ore Company of Liberia (NIOC) Rail Road is operating on the line } \\
\text { connecting the mine at Mano River with the Bomi Hill line (62 km from the Port of } \\
\text { Monrovia). The Liberian American-Swedish Mineral Company (LAMCO) Rail } \\
\text { Road is operating on the line from Yekepa to the Port of Buchanan to ship iron ore. } \\
\text { The Bong Mining Company (BMC) Rail Road is operating on the line from Bong } \\
\text { Mine Range in Bong County to Monrovia }\end{array}$ & No \\
\hline Mali & $\begin{array}{l}\text { Régie des Chemins de fer du Mali (RCFM). Responsible for the operation of the } \\
\text { Mali railway. } \\
\text { Ministry of Equipment, Transport, and Disenclavement (METD). Responsible for } \\
\text { the administration of the transport sector in Mali through the development and } \\
\text { implementation of the national policy in the field of equipment and transport, and } \\
\text { the supervision of autonomous organizations. } \\
\text { National Directorate of Land, Maritime and Inland Transport (DNTTMF). } \\
\text { Responsible for drawing the elements of the national road, rail, maritime and river } \\
\text { transport policy, and for coordinating and controlling the external, regional and } \\
\text { related services and the public and private bodies involved in the field of transport. }\end{array}$ & No \\
\hline Nigeria & $\begin{array}{l}\text { Nigerian Railway Corporation (NRC). Stated-owned enterprise with exclusive } \\
\text { rights to operate railways in Nigeria. The public corporation created by an Act of } \\
\text { Parliament in 1955. Responsible for passengers and freight transport. } \\
\text { The Federal Ministry of Transport. The political authority concerned with the } \\
\text { activities of the NRC. Responsible for creating an enabling environment for the } \\
\text { provision and implementation of effective national transport policies. }\end{array}$ & Yes \\
\hline Senegal & $\begin{array}{l}\text { Agence des Nouveaux Chemins de Fer (ANCF). Responsible for the planning, } \\
\text { coordination, search for public and private funding for new railway infrastructure, } \\
\text { but not proper regulation of railways. } \\
\text { Ministry of Infrastructure and Land Transportation. Detains political } \\
\text { responsibility for transport infrastructure except for ports. } \\
\text { Petit Train Bleu (PTB). The public company handling passenger services on the line } \\
\text { Dakar Rufisque-Thiès line. } \\
\text { Ministry of Finance through its different directions units (Direction of Public Sector, } \\
\text { Direction of Budget and Direction of Economic and Financial Cooperation). Proposes } \\
\text { the Government agents on the Board of Directors of Transrail; sets and arranges the } \\
\text { subsidy for PTB; and deal with multilateral and bilateral financial agencies. }\end{array}$ & No \\
\hline Sierra Leone & MMR. Responsible for the administration of the railway transport sector & No \\
\hline Togo & $\begin{array}{l}\text { M.M. Mining, Togo Rail and Société Nouvelle des Phosphates du Togo (SNPT); } \\
\text { the three rails operators. } \\
\text { Directorate of Road and Railway Transport (DTRF) under the Directorate } \\
\text { General of Transport (DGT). The administrative department for the concession and } \\
\text { administration of the railway. Responsible for ensuring a safe, efficient and reliable } \\
\text { railway transport system to assist the movement of goods, people and services. }\end{array}$ & No \\
\hline
\end{tabular}

In the Benin Republic, the rehabilitation of $438 \mathrm{~km}$ of the railroad from Parakou to Cotonou, and the extension of remained $450 \mathrm{~km}$ to be built to reach $594 \mathrm{~km}$ of the planned route from Nigerien capital (Niamey) to Northern Benin (Parakou) is assigned to China Railway Construction Corporation (CRCC) at a cost of $\$ 4$ bn (L. M. Afrique, 2018). In Burkina Faso, the modernization of the infrastructure and the increase of the rail network capacity will be undertaken by the Bolloré group over a 5-year period at a cost of CFA franc 262 bn (BIRBA, 2015). In addition to infrastructure-related investments, the group has also committed around CFA franc 20 billion to renew the rolling stock, in order to increase the FASO traction capacity of freight trains (BIRBA, 2015).

In Ghana, the revamping and transformation of the railway sector are designed by the Ghana Railway Master Plan (RMP) and include the rehabilitation, improvement, and modernization of the existing railway infrastructure; the expansion of railway infrastructure to other parts of the country and linking with neighboring countries such as the Ivory Coast, Togo, and Burkina Faso; and the interconnection of railway infrastructure with other modes of transportation (inter-modalism) (GRDA, 2013). The expansion of the national railway network will be realized by the construction of new standard gauge lines to ensure a more complete transportation service for the whole country. The rehabilitation and this expansion will be developed in 6 phases interventions (GRDA, 2013). The first phase includes the rehabilitation of Western (Takoradi-Kumasi and Dunkwa-Awaso) and Eastern (Accra-Kumasi and Achimota-Tema) lines. The second phase involves the doubling of the two lines restructured in Phase 1, by constructing the standard gauge lines: Takoradi-Kumasi ( $2 \mathrm{~W}$ ) and AccraKumasi ( $2 \mathrm{E}$ ) and the conversion to the standard gauge of the previously restructured track. The third phase involves the construction of the single track, standard gauge, and transversal lines for the routes 
Tamale-Yendi, Fufulsu-Sawla, Techiman-Kwadwokurom, and Nyinahin-Kumasi. The fourth phase sees the construction of two single tracks, standard gauge lines. The first section of the line starts from Aflao, near the border with Togo and heads West, mainly along the coast of the Gulf of Guinea, connecting the important cities of Tema, Accra, Cape Coast, and Takoradi. The second section starts at Tarkwa and ends at Omanpe, near the border with the Cote D'Ivoire. The fifth phase sees the construction of a single, standard gauge line that extends the original Western Line northwards to reach and connect the future mines. The line starts from Dunkwa-Awaso and extends as far as Techiman, Sawia, and Hamile. The last phase sees the construction of a single, standard gauge line heading east, near the border with Togo, that from Tema reaches the river port of Akosombo and then heads towards Ho and Yendi in the North.

The financial investments of all 6 phases of the Master Plan are estimated at a cost of $\$ 21.508$ million for the infrastructures and \$1254 million for the rolling stock (GRDA, 2013).

In Guinea, the Dapilon-Santou rail project is a new 135km-long railroad facility being built to connect the Santou mining zone and the Port of Dapilon in Guinea. At an estimated cost of \$3bn investment from the SMB-Winning consortium, the railroad will enable faster and more efficient transportation of bauxite to the docks in high concentration, and help to expand the mining zone while reducing the corporate transportation cost. In addition, there is an agreement of the Chinese-backed international consortium to build a $650 \mathrm{~km}$ Standard Gauge Railway (SGR) and a deepwater port at a cost of $\$ 14 \mathrm{bn}$. This is in exchange for permission to mine a massive, untapped deposit of high-grade iron ore in the West African country.

In Ivory Coast, ceremonies were held to mark the formal start of work on a long-awaited project to rehabilitate the $1260 \mathrm{~km}$ Abidjan-Ouagadougou metre-gauge railway at a cost of FCFA $262 \mathrm{bn}(\mathrm{J}$. Afrique, 2018). In addition, studies and funding research were carried out to assist numerous projects such as (i) the construction of the San Pedro-Bamako railway for the exploitation of minerals; (ii) the construction of the $338 \mathrm{~km}$ Ouangolo-Niellé-Sikasso-Bougouni railway at a cost of CFA franc $240 \mathrm{bn}$, including $86 \mathrm{~km}$ in Ivory Coast; (iii) the construction of the $181 \mathrm{~km}$ long Man-Nzérékoré (Guinea Conakry) railway at a cost of CFA franc $127 \mathrm{bn}$; and (iv ) the "RAIL CITY" project at a cost of CFA franc 300 bn to revalue the landholdings of SIPF in Plateau district (J. Afrique, 2018).

In Liberia, the Nimba railway is due for rehabilitation under the terms of an MDA (Mineral Development Agreement) with Arcelor Mittal, the company which has resumed exploitation of the former LAMCO mines in Nimba (Graham et al., 2012). The government of Liberia is requiring that the line be reconstructed to allow for multiple uses, as a result of which the investment cost will be considerable. China Union is rehabilitating the Bong mines (formerly operated by German company Thyssen), for which it is operating the Bong railway with limitations. The capital expenditure required for the Bong railway and connected mineral pier in Monrovia is estimated at around \$ 350 million and China Union will have the obligation to undertake this infrastructure investment (Graham et al., 2012). Consideration is being given to the construction of a new railway to the Putu range in the coming years to evacuate the large scale find of iron ore found in the Putu mineral deposit (Graham et al., 2012).

In Mali, the rehabilitation of the Dakar-Bamako line is categorized into four possible options: (1) rehabilitation of Dakar-Bamako metric gauge track to ensure minimum safety (traffic below 700,000 tones/year) at a cost of \$ 144 million, (2) rehabilitation of Dakar-Bamako metric gauge track to ensure minimum traffic (traffic less than 3 million tones/year) at a cost of \$280 million, (3) rehabilitation of Dakar-Bamako metric gauge track to ensure high traffic (traffic between 3 and 10 million tones/year) at a cost of $\$ 495$ million, and (4) Change from metric gauge to standard gauge (traffic over 10 million tones/year) at a cost of $\$ 1.515$ bn (BAD, 2014). In addition, the rail interconnection project was planned between the countries of Mali, Guinea, and Ivory Coast (Conakry- Kankan-MandianaBougouni-Bamako) at a cost of $\$ 724.080$ million (BAD, 2014).

In Nigeria, two significant standard-gauge rail projects are financed by the Chinese (Chen, 2018). The rehabilitation of the Western trunk line from Lagos to Kano is the first one and replaced the colonial track. Of the scheduled route, the 187-kilometer Abuja-Kaduna single-track SGR was first to be built in 2014, at a cost of $\$ 874$ million. The 312-kilometer Lagos-Ibadan segment is the next in the construction process by the China Civil Engineering Construction Company (CCECC) at a cost of $\$ 1.2$ bn. Financing for the $\$ 1.1$ bn Kano-Kaduna segment is still under negotiation. The new coastal railway linking Lagos to Calabar, via Warri and Port Harcourt, to include branch lines to Benin City and Onitsha is the second significant project. It was suggested by CCECC as part of three East-West routes that 
would traverse the colonial trunk lines. The contract for the project is noted to be worth $\$ 11$ bn and signed with CCECC in 2016. In April 2017, a loan request to the Exim Bank of China has been approved by the Nigerian senate and comprises $\$ 3.5$ bn for the coastal project.

In Senegal, the revival of rail infrastructure is one of the major projects of President Macky Sall. Thus, clear prospects are emerging for the rail network within the framework of the Emerging Senegal Plan (PSE). The Dakar Regional Express Train (TER), which was put into service at the end of 2018 is its presidency flagship project (Afrique, 2016). Following the consecutive meetings in Beijing and Paris with the Advisory Group, an ambitious program to build 1,520 km of new lines has been drawn up, at a total cost of CFA franc $1.390 \mathrm{bn}$. The goal is to modernize railway infrastructure between Dakar and Thiès and to build a double-track standard gauge, serving the Blaise Diagne International Airport (AIBD); to construct a new $1000 \mathrm{~km}$ structuring standard track gauge between Dakar-TambacoundaKédougou-Kéniéba-Bamako, commonly called Dakar-Bamako by the South. In addition, the current Dakar-Tambacounda-Kidira-Bamako line will be completely rehabilitated. It is an extremely important corridor for supplying Mali with various products from transit operations at the port of Dakar, and for accessing the sub-regional market of the West African Economic and Monetary Union (WAEMU). Senegalese President Macky Sall promised to build a railway connecting Dakar to Ziguinchor, the capital of Casamance (southwest of the country) at a cost of \$ 500 million (Ecofin, 2015).

In Sierra Leone, China Kingho Energy Group, one of China's largest privately-owned energy groups has planned to construct a $250-\mathrm{km}$ railway from the northern Tonkolili district to the coastal town of Sulima at a cost of $\$ 6$ bn (Angel, 2014). At present, Togo Rail is extending the Kpalimé line to Aflao in Ghana. This project also requires the rehabilitation of the Lomé-Kpalimé line linking the Tokoin water tower and the Totsi/Djidjole junction (about $3 \mathrm{~km}$ ) (JICA, 2013). The new line length in Togo is $2 \mathrm{~km}$, that in Ghana is $2 \mathrm{~km}$ and the total including sidings in Aflao is $8 \mathrm{~km}$. The cost is estimated at CFA franc 1,300 million. Another line extension project connecting Blitta to Ouagadougou under the Africa rail project is planned, aiming at constructing $761 \mathrm{~km}$ of new railway lines to interconnect their existing (JICA, 2013).

\section{Conclusion}

Sustainable railway transport has proved to play a crucial role than road mode when socioeconomic and environmental costs are considered. The greenhouse gas emission per passenger-km and tonne-km is seen to be reduced for railway transport in contrast to the road. This paper describes the past, present, and future development of the railway transportation system in West Africa. The current situation of railways shows their obsolescence state because of a lack of maintenance and limited investment. As a consequence, railways networks in this region have been characterized by low traffic densities which reduce their competitiveness against the road transport mode. In recent years, the sector has shown a global revival through the rehabilitation of existing lines and the construction or planning of new lines.

\section{Funding}

The authors received no direct funding for this research.

\section{Citation information}

Bayane, B. M., \& Yanjun, Q. (2020). Past, present and future development of West African railways. Journal of Sustainable Development of Transport and Logistics, 5(1), 103-114. doi:10.14254/jsdtl.2020.5-1.10 


\section{References}

Ademiluyi, I. (2006). Rail transport system in Nigeria: It contributions, constraints and the way forward. Knowledge Review, 12(4), 1-8.

Adesanya, A. (2010). Bringing the Nigerian railways back on track: challenges and options. Paper presented at the NISER Seminar Series.

AfDB. (2015). Rail Infrastructure in Africa: Financing Policy Options. from African Development Bank.

Afrique, J. (2016). Abdou Ndéné Sall: « Le Sénégal va construire 1500 kilomètres de lignes ferroviaires en cinq ans ». Available online: https://www.jeuneafrique.com/346057/economie/abdou-ndenesall-senegal-va-construire-1-500-kilometres-de-lignes-ferroviaires-cinq-ans/ (accessed on 01 August 2016)

Afrique, L. M. (2018). Ni Bolloré ni Petrolin: pour le train, le président béninois préfère Pékin. Available online: https://www.lemonde.fr/afrique/article/2018/03/23/ni-bollore-ni-petrolinpour-le-train-le-president-beninois-prefere-pekin_5275222_3212.html (accessed on 23 March 2018).

Agbaeze, E., \& Onwuka, I. (2014). Boosting railway system infrastructure in Nigeria: The public-private partnership option. Journal of Business Administration and Management Sciences Research, 3(3), 39-48.

Angel, M. (2014). New railway from Tonkolili to Sulima as China plans $\$ 6$ billion investment in Sierra Leone. Available online: https://cocorioko.net/new-railway-from-tonkolili-to-sulima-as-chinaplans-6-billion-investment-in-sierra-leone/ (Accessed on April 10, 2014).

BAD. (2014). Mali, Note sur le secteur des transports. Département des Transports, du Développement Urbain et des TIC.

Bayane, B. M., \& Yanjun, Q. (2017). Transport infrastructure development in China. Journal of Sustainable Development of Transport and Logistics, 2(1), 29-39.

Bayane, B. M., Yanjun, Q., \& Bekhzad, Y. (2020). A review and analysis of railway transportation system in the economic community of West African States: Towards the development of sustainable regional goal. Global Journal of Engineering and Technology Advances, 2(2), 011-022.

BIRBA, G. (2015). Le chemin de fer Kaya/Abidjan. Available online: https://www.leconomistedufaso.bf/2015/09/28/le-chemin-de-fer-kayaabidjan/ (accessed on 09 September 2015).

Bouraima, M. B., \& Dominique, C. M. D. (2018). Road Infrastructure and Economic Growth in Benin Republic. Scholars Bulletin (Civil Engineering), 4(7), 680-688.

Bouraima, M. B., \& Qiu, Y. (2018). Toward Innovative Solutions for Revitalizing Benin Republic Railway Transportation System. Paper presented at the International Conference on Transportation and Development 2018: Traffic and Freight Operations and Rail and Public Transit.

Bouraima, M. B., Qiu, Y., Yusupov, B., \& Ndjegwes, C. M. (2020). A study on the development strategy of the railway transportation system in the West African Economic and Monetary Union (WAEMU) based on the SWOT/AHP technique. Scientific African, e00388.

Bouraima, M. B., Yang, E., \& Qiu, Y. (2017). Mechanics Calculation of Asphalt Concrete Tracksubstructure Layer and Comparisons. American Journal of Engineering Research (AJER), 6, 280287.

Brou, K. A. (2015). L'EXPLOITATION COLONIALE DANS LA MISE EN PLACE DU RÉSEAU ROUTIER ET FERROVIAIRE DE LA COLONIE DE CÔTE D'IVOIRE DE 1893 A 1960.

Bullock, R. (2009). Off Track: Sub-Saharan African Railways. Africa Infrastructure Country Diagnostic Background Paper, 17.

Captain H.O. Mance D.S.O., R. E. (1913). The Railway Systems of West Africa. Royal United Services Institution Journal, 57(420), 27 pages.

Chen, Y. (2018). China's Role in Nigerian Railway Development and Implications for Security and Development.

Debrie, J. (2001). De la continentalité à l'Etat enclavé: circulation et ouvertures littorales des territoires intérieurs de l'ouest africain. Université du Havre.

Ecofin, A. (2015). Sénégal: Macky Sall promet de construire un chemin de fer Dakar- Ziguinchor pour 500 millions \$. Available online: https://www.agenceecofin.com/investissement/2002-26726- 
senegal-macky-sall-promet-de-construire-un-chemin-de-fer-dakar-ziguinchor-pour-500-millions (accessed on 20 February 2015).

Foster, V., Butterfield, W., \& Chen, C. (2009). Building bridges: China's growing role as infrastructure financier for Africa: The World Bank.

Graham, E. G., Garrido, L., \& Karjanlahti, A. (2012). Liberia: Inclusive Growth Diagnostics. Available at SSRN 2305698.

GRDA. (2013). Ghana Railways Master Plan-Final Report.

Gwilliam, K. (2011). Africa's transport infrastructure: Mainstreaming maintenance and management: The World Bank.

Jaekel, F. (1997). The history of the Nigerian railway (Vol. 2): Spectrum Books.

Jedwab, R., Kerby, E., \& Moradi, A. (2017). How colonial railroads defined Africa's economic geography.

Jedwab, R., \& Storeygard, A. (2019). Economic and political factors in infrastructure investment: evidence from railroads and roads in Africa 1960-2015. Economic History of Developing Regions, $34(2), 156-208$.

JICA. (2013). The Project for The Study on Togo Logistics Corridor Development in The Republic of Togo. Chapter 3 Current Transport System in Togo. FINAL REPORT. Retrieved from THE REPUBLIC OF TOGO:

Mabogunje, A. (2015). The development process: A spatial perspective: Routledge.

Metcalfe, C. (1916). Railway development of Africa, present and future. The Geographical Journal, 47(1), 3-17.

Nana, M. (1984). Héritage colonial et développement: rôle historique et socio-économique du chemin de fer Abidjan-Niger dans le développement de la Haute-Volta (l'actuelle Burkina-Fasso).

Ogunremi, G. O., \& Faluyi, E. (1996). Economic History of West Africa: Rex Charles Publication.

Olievschi, V. N. (2013). Rail transport: Framework for improving railway sector performance in SubSaharan Africa.

Pourtier, R. (2007). Les chemins de fer en Afrique subsaharienne, entre passé révolu et recompositions incertaines. Belgeo. Revue belge de géographie(2), 189-202.

Robinson, J. C. (2007). "Tout Travail Doit Nourrir Son Homme" The Dakar-Niger Railroad and the 1947-1948 Strike in the Political and Labor History of Senegal. ISP Collection, 189.

Scotto, G. (2018). Colonial and Postcolonial Logistics. FOOTPRINT, 69-86.

Sunderland, D. (2017). Communications in Africa, 1880-1939, Volume 5: Routledge.

Taaffe, E. J., Morrill, R. L., \& Gould, P. R. (1963). Transport expansion in underdeveloped countries: a comparative analysis. Geographical review, 53(4), 503-529.

Thomas, B. E. (1957). Railways and Ports in French West Africa. Economic Geography, 33(1), 1-15.

Union, A. (2015). Agenda 2063: the Africa we want. African Union Commission.

Union, E. (2004). Commission Decision 2004/446/EC of 29 April. Retrieved from Brussels, Belgium

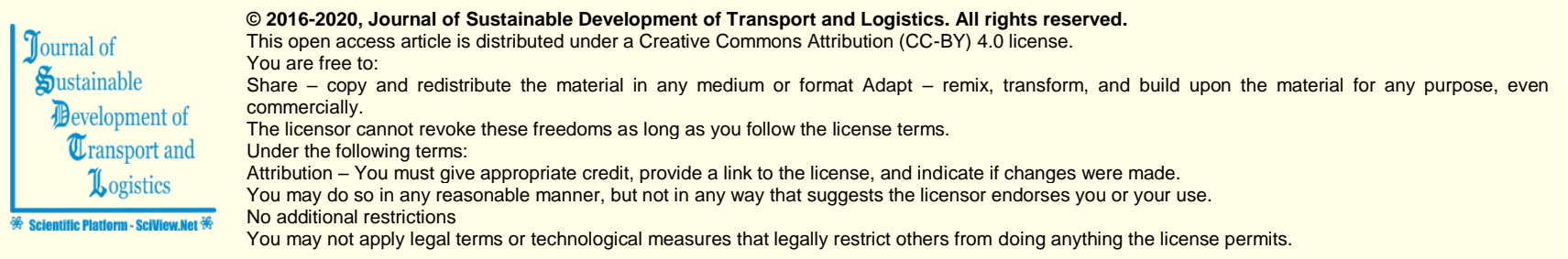

Journal of Sustainable Development of Transport and Logistics (ISSN: 2520-2979) is published by Scientific Publishing House "CSR", Poland, EU and Scientific Publishing House "SciView", Poland, EU

Publishing with JSDTL ensures:

- Immediate, universal access to your article on publication

- High visibility and discoverability via the JSDTL website

- Rapid publication

- Guaranteed legacy preservation of your article

- Discounts and waivers for authors in developing regions

Submit your manuscript to a JSDTL at https://jsdtl.sciview.net/ or submit.jsdt!@sciview.ne 